\title{
Arsenite and arsenate removals from groundwater by electrocoagulation using iron ball anodes: Influence of operating parameters
}

\author{
E. Ş1k ${ }^{\mathrm{a}}$, E. Demirbas ${ }^{\mathrm{b}, *}$, A.Y. Goren ${ }^{\mathrm{c}}$, M.S. Oncel ${ }^{\mathrm{d}}$, M. Kobya ${ }^{\mathrm{d}}$ \\ a Tubitak Marmara Research Center, Environment and Cleaner Production Institute, 41470 Gebze, Kocaeli, Turkey \\ b Department of Chemistry, Gebze Technical University, 41400 Gebze, Turkey \\ c Department of Environmental Engineering, Izmir Institute of Technology, 35430 Izmir, Turkey \\ d Department of Environmental Engineering, Gebze Technical University, 41400 Gebze, Kocaeli, Turkey
}

\section{A R T I C L E I N F O}

\section{Keywords:}

Arsenite and arsenate removals

Electrocoagulation

Iron ball electrode

Groundwater

Operating cost

\begin{abstract}
A B S T R A C T
Removals of arsenite (As(III)) and arsenate (As(V)) from groundwater by a cylindrical packed-bed electrocoagulation (EC) reactor using Fe ball anodes were investigated in this study. Effects of some operating parameters such as initial $\mathrm{pH}\left(\mathrm{pH}_{\mathrm{i}}\right.$ of $\left.6.5-8.5\right)$, applied current ( $i$ of $\left.0.075-0.30 \mathrm{~A}\right)$, initial concentration $\left(C_{\mathrm{o}}\right.$ of $30-200 \mu \mathrm{g} / \mathrm{L})$, diameter of iron ball $\left(d_{\mathrm{p}}\right.$ of 5.0-10.0 mm), height of anode balls in the reactor $(h$ of $2-8 \mathrm{~cm})$ and airflow rate $\left(Q_{\text {air }}\right.$ of $\left.0.0-6.0 \mathrm{~L} / \mathrm{min}\right)$ on the removal efficiency of arsenic were evaluated. The removal efficiency of arsenic decreased with increase in concentrations of arsenic from 30 to $200 \mu \mathrm{g} / \mathrm{L}$ while its removal efficiency increased with increase in operating time, applied current, height of anode in the reactor, and airflow rate. The optimum operating conditions for effective As(III) and As(V) removals to meet the permissible level of arsenic effluent concentration of $<10 \mu \mathrm{g} / \mathrm{L}$ were determined as $0.3 \mathrm{~A}, 14 \mathrm{~min}$ of EC time for As(III) and $12 \mathrm{~min}$ for As (V), a $\mathrm{pH}_{\mathrm{i}}$ of $7.5, C_{\mathrm{o}}$ of $200 \mu \mathrm{g} / \mathrm{L}, d_{\mathrm{p}}$ of $7.5 \mathrm{~mm}, h$ of $7.5 \mathrm{~cm}$ and $Q_{\mathrm{air}}$ of $6 \mathrm{~L} / \mathrm{min}$, respectively. Arsenic removal efficiency, energy and electrode consumptions, operating cost, charge loading and arsenic removed capacity per amount of electrochemically generated $\mathrm{Fe}$ at the optimum conditions were also calculated as $96.0 \%, 1.442 \mathrm{kWh} /$ $\mathrm{m}^{3}, 0.0752 \mathrm{~kg} / \mathrm{m}^{3}, 0.612 \$ / \mathrm{m}^{3}, 252 \mathrm{C}$ and $2.55 \mu \mathrm{g} / \mathrm{mg} \mathrm{Fe}(0.762 \mu \mathrm{g} / \mathrm{C})$ for As(III) removal and $95.8 \%$, $1.386 \mathrm{kWh} / \mathrm{m}^{3}, 0.0628 \mathrm{~kg} / \mathrm{m}^{3}, 0.546 \$ / \mathrm{m}^{3}, 216 \mathrm{C}$ and $3.05 \mu \mathrm{g} / \mathrm{mg}$ Fe $(0.887 \mu \mathrm{g} / \mathrm{C})$ for As(V) removal, respectively.
\end{abstract}

\section{Introduction}

Elevated concentrations of arsenic in groundwater and other natural waters with geogenic sources occur in many areas around the world [1-3]. Processes of arsenic mobilization from sediments may vary depending on the hydro-geochemical characteristics of the aquifer, the presence of oxidized and/or reduced mineral phases and the cofactors associated with arsenic-rich solid phases [3]. Long term exposure to high levels of arsenic can cause a wide range of health effects including skin lesions such as hyperkeratosis and pigmentation changes, circulatory disorders, diabetes and cancers of bladder, lung, kidney and skin $[4,5]$. Thus, the World Health Organization (WHO) and the United States Environmental Protection Agency (US-EPA) have revised the guideline for arsenic maximum contaminant level (MCL) in drinking water from 50 to $10 \mu \mathrm{g} / \mathrm{L}$ [6,7]. The arsenic threat also affects many countries including Argentina, Bangladesh, Cambodia, Chile, China, Hungary, India, Japan, Laos, Mexico, Myanmar, Nepal, Turkey, USA, Vietnam, etc. $[2,3,8]$.
Naturally elevated arsenic concentrations are common in the WestAnatolia of Turkey, particularly in geothermal waters and groundwaters in borate mines areas. Recently, numerous cases of natural arsenic pollution in these waters have been reported namely, Igdeköy $(10-10,700 \mu \mathrm{g} / \mathrm{L})$ and Dulkadir $(300-500 \mu \mathrm{g} / \mathrm{L})$ villages of KütahyaEmet [9-11], Kütahya-Hisarcik (10-3000 $\mu \mathrm{g} / \mathrm{L})$ [12], Balikesir-Bigadiç (33-911 $\mu \mathrm{g} / \mathrm{L})$ [13], Kütahya-Simav Plain (0.5-562 $\mu \mathrm{g} / \mathrm{L})$ [14], İzmirBalçova Plain (1-182 $\mu \mathrm{g} / \mathrm{L})$ [15], and Eskisehir-Kırka (7-150 $\mu \mathrm{g} / \mathrm{L})$ $[16,17]$.

The USEPA proposed the best available technologies (BAT) for arsenic removal to achieve compliance with MCL from small water facilities such as ion exchange (95\%), activated alumina (95\%), reverse osmosis (> 95\%), modified coagulation/filtration (95\%), modified lime softening (90\%), and electrodialysis (85\%). In addition, iron oxidecoated sand, manganese green sand filtration, iron filings, and granular ferric hydroxide were classified as emerging technologies by USEPA $[18,19]$. Drawbacks of these arsenic removal technologies forced municipalities and various industries to search for effective alternative

\footnotetext{
* Corresponding author.

E-mail address: erhan@gtu.edu.tr (E. Demirbas).
} 
treatment technologies for the arsenic removal, ideally by electrochemical methods [20]. Electrocoagulation (EC) is one of the most efficient technologies for removal of both As(III) and As(V) from contaminated water [21-23]. Recently, Amrose et al. [24] reported that real groundwater samples with arsenic concentrations of $80-760 \mu \mathrm{g} / \mathrm{L}$ from Bangladesh and Cambodia in 100 and $600 \mathrm{~L}$ of EC reactors (named as ECAR) were reduced to $<10 \mu \mathrm{g} / \mathrm{L}$. The operating cost was varied in the range of $0.22-1.04 \$ / \mathrm{m}^{3}$. The EC is a very promising treatment process for the arsenic removal because of some advantages such as no addition of chemicals or regeneration, a shortened reactive retention time, higher removal efficiency, no $\mathrm{pH}$ adjustment, no chemical requirement for pre-oxidation of $\mathrm{As}(\mathrm{III})$ to $\mathrm{As}(\mathrm{V})$, simplicity in operation, compact treatment facility, and relatively cost-effectiveness [20,21,25].

The most important parameters affecting removal of arsenic from waters were current density, reaction time, arsenic species, type and shape of electrodes, geometry of electrodes and airflow rate in the EC process. Plate and rod types of $\mathrm{Al}$ or $\mathrm{Fe}$ anode electrodes were generally used in the EC reactors and these had some disadvantages namely, its being time consuming (changing and maintenance) and accommodating a limited number of plate and rod types of electrodes with low surface areas. Therefore, an air-injected EC reactor was used to eliminate the above problems. The new EC reactor using Fe ball electrodes was reported in earlier studies $[21,26]$. The new EC reactor had specifications of compactness, ease of use, accommodating more anode electrodes with higher surface areas, and providing better removal efficiency.

In this study, As(III) and As(V) removals from the groundwater by a cylindrical packed-bed EC reactor using iron ball anodes were performed to determine the optimum operating conditions. For that reason, effects of operating parameters such as initial $\mathrm{pH}$, applied current, initial arsenic concentration, diameter of Fe ball anode, Fe ball anode height in the EC reactor, airflow rate and operating time on the arsenic removal efficiencies were evaluated. Energy, electrode consumptions, and operating cost for the removal were also calculated.

\section{Material and methods}

\subsection{Characterization of groundwater}

Real groundwater was obtained from a well situated in the province of Kocaeli in Turkey and stored in five tones high-density polyethylene container. All chemical species present in groundwater were determined with standard methods [27]. The concentrations of cations, $\mathrm{Ca}, \mathrm{Mg}, \mathrm{Mn}, \mathrm{Na}$, and Si by ICP optical emission spectrometry (PerkinElmer ICP-OES Optima 7000 DV) and anions such as nitrate, sulphate, and chloride by ion chromatography (Shimadzu HIC-20A) were measured in the groundwater. The groundwater was characterized as a $\mathrm{pH}$ of 7.6, conductivity of $1055 \mu \mathrm{S} / \mathrm{cm}$, dissolved organic carbon of $5 \mathrm{mg} / \mathrm{L}$, total alkalinity of $260 \mathrm{mg} \mathrm{CaCO} / 3 / \mathrm{L}$, total hardness of $418 \mathrm{mg} \mathrm{CaCO} / \mathrm{L}$, total $\mathrm{Mn}$ of $0.006 \mathrm{mg} / \mathrm{L}$, total silica of $10.18 \mathrm{mg} / \mathrm{L}$, total sulphate of $94.2 \mathrm{mg} / \mathrm{L}$ and total nitrate of $24.0 \mathrm{mg} / \mathrm{L}$. Fe, Al, P, and F in the real groundwater were not detected. The groundwater containing arsenic concentration of $30-200 \mu \mathrm{g} / \mathrm{L}$ was prepared daily using sodium arsenate $\left(\mathrm{Na}_{2} \mathrm{HAsO}_{4} \times 7 \mathrm{H}_{2} \mathrm{O}\right)$ or sodium arsenite $\left(\mathrm{NaAsO}_{2}\right)$ salts.

\subsection{Experimental setup}

A batch mode of the cylindrical packed-bed EC reactor (acrylic electrochemical cell with a total volume of $2041 \mathrm{~cm}^{3} ; 100 \mathrm{~mm}$ in diameter and $260 \mathrm{~mm}$ in height) was used for removal of the groundwater containing arsenic in Fig. 1. An iron (Fe) ball as anode and cylindrically porous titanium ( $\mathrm{Ti}$ ) as cathode $(70 \mathrm{~mm}$ in diameter, $255 \mathrm{~mm}$ in height and $3 \mathrm{~mm}$ in thickness) were used in the EC reactor. The groundwater sample $(0.95 \mathrm{~L})$ containing As(III) or As(V) was placed in the EC reactor (Fig. 1). The anode and cathode were connected to a digital DC power supply (Agilent 6675A; $120 \mathrm{~V}$ and $18 \mathrm{~A}$ ). An air-fed diffuser was attached underneath the reactor and the air was fed continuously at different rates in the reactor to maintain uniform shaking. The electrical current was adjusted to a desired value by the DC power supply and the experimental operation was started. The samples were periodically taken from the reactor during the EC process and then analysed.

\subsection{Analytical methods}

The arsenic concentration in the groundwater samples was determined by an atomic absorption spectrometer (Perkin-Elmer SIMAA 6000 AAS) equipped with a manual hydride generator (MSH-10, PerkinElmer) at $188.9 \mathrm{~nm}$ wavelength. The detection limit of this study was $0.10 \mu \mathrm{g} / \mathrm{L}$ and analysis of the duplicates was within $2 \%$ of errors. $\mathrm{pH}$ of the solutions was adjusted by $0.10 \mathrm{~N} \mathrm{NaOH}$ or $0.10 \mathrm{~N} \mathrm{H}_{2} \mathrm{SO}_{4} \cdot \mathrm{pH}$ and conductivity of solutions before and after the EC process were measured by a pH meter (Mettler Toledo Seven Compact) and a conductivity meter (Mettler Toledo Seven Go), respectively.

\section{Mechanism of arsenic removal in the EC process}

When a charge is applied through an external power source, the electrolytic dissolution of sacrificial anode produces the cationic monomeric species according to the following Eqs. ((1)-(3)):

$4 \mathrm{Fe}_{(\mathrm{s})} \rightarrow 4 \mathrm{Fe}^{2+}+8 \mathrm{e}^{-}$

$4 \mathrm{Fe}_{(\mathrm{s})} \rightarrow 4 \mathrm{Fe}^{3+}+12 \mathrm{e}^{-}$

$\mathrm{Fe}^{2+} \rightarrow \mathrm{Fe}^{3+}+\mathrm{e}^{-}$

$\mathrm{Fe}(\mathrm{II})$ forms highly reactive oxidizing species [Fe(IV)] during oxidation which can oxidize As(III) to As (IV) [28]. This affects oxidation of $\mathrm{Fe}(\mathrm{II})$ and effective $\mathrm{Fe}(\mathrm{IV})$ utilization such as $\mathrm{pH}$, dissolved oxygen for removal of arsenic.

The increase in $\mathrm{pH}$ during the EC is primarily attributed to the increase in hydroxyl ion concentration in solution resulting from reduction of water at the cathode (Eqs. (4) and (5)).

$2 \mathrm{H}_{2} \mathrm{O}+2 \mathrm{e}^{-} \rightarrow \mathrm{H}_{2(\mathrm{~g})}+2 \mathrm{OH}^{-}$

$8 \mathrm{H}^{+}+8 \mathrm{e}^{-} \rightarrow 4 \mathrm{H}_{2(\mathrm{~g})}$

The rate of the oxidation depends on the availability of dissolved oxygen (Eq. (6)). Typically at the cathode, the solution becomes alkaline with time. The applied current forced hydroxyl ion migration towards the anode favors ferric hydroxide formation (Eq. (7)). $\mathrm{Fe}^{2+}$ ions released from anode are gradually hydrolyzed and form $\mathrm{Fe}(\mathrm{OH})_{3(\mathrm{~s})}$. Thus, the removal of arsenic species from solution is sorption onto the freshly precipitated $\mathrm{Fe}(\mathrm{OH})_{3(\mathrm{~s})}$ particles or flocs

$4 \mathrm{Fe}^{2+}+2 \mathrm{H}_{2} \mathrm{O}+\mathrm{O}_{2(\mathrm{~g})} \rightarrow 4 \mathrm{Fe}^{3+}+4 \mathrm{OH}^{-}$

$\mathrm{Fe}^{3+}+3 \mathrm{OH}^{-} \rightarrow \mathrm{Fe}(\mathrm{OH})_{3(\mathrm{~s})}$

Iron is dissolved giving rise to ferrous ions and its oxidation occurs in the following reaction.

$\mathrm{Fe}^{2+}+3 \mathrm{OH}^{-} \rightarrow \mathrm{FeOOH}+2 \mathrm{H}_{2} \mathrm{O}+\mathrm{e}^{-}$

Ferric ions generated by electrochemical oxidation of iron electrode may form monomeric species with respect to $\mathrm{pH}$ of the medium, $\mathrm{Fe}$ $(\mathrm{OH})$, and polymeric hydroxyl complexes such as $\mathrm{Fe}(\mathrm{OH})^{2+}, \mathrm{Fe}(\mathrm{OH})_{2}{ }^{+}$, $\mathrm{Fe}_{2}(\mathrm{OH})_{2}{ }^{4+}, \quad \mathrm{Fe}(\mathrm{OH})_{4}{ }^{-}, \quad \mathrm{Fe}\left(\mathrm{H}_{2} \mathrm{O}\right)_{2}{ }^{+}, \quad \mathrm{Fe}\left(\mathrm{H}_{2} \mathrm{O}\right)_{5}(\mathrm{OH})^{2+}, \quad \mathrm{Fe}$ $\left(\mathrm{H}_{2} \mathrm{O}\right)_{4}(\mathrm{OH})_{2}{ }^{+}, \mathrm{Fe}\left(\mathrm{H}_{2} \mathrm{O}\right)_{8}(\mathrm{OH})_{2}{ }^{4+}$, and $\mathrm{Fe}_{2}\left(\mathrm{H}_{2} \mathrm{O}\right)_{5}(\mathrm{OH})_{4}{ }^{2+}$. These iron hydroxides/polyhydroxides compounds (HFO) have strong affinity for arsenic species. Generally FeOOH produced in the EC has an isoelectric $\mathrm{pH}$ of about 7.0. Above the isoelectric point, both arsenic species and FeOOH surface are negatively charged and adsorption is less favorable $[21,26]$. Hydrous ferric oxides such as amorphous ferric hydroxide, ferrihydrite, lepidocrocite, and goethite strongly sorb both As(V) and As (III) [29-31]. Iron(III) oxyhydroxides can also participate in the 

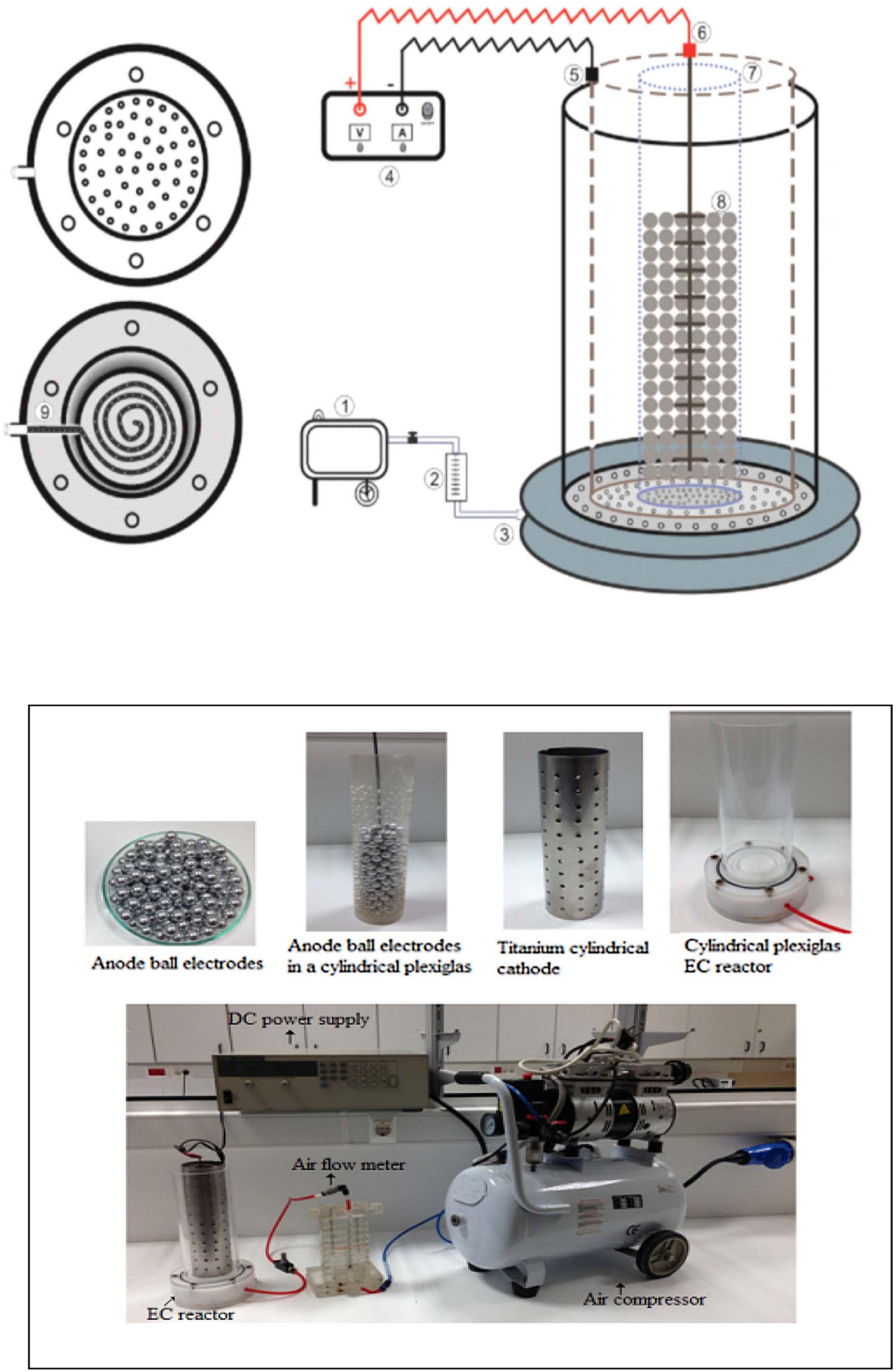

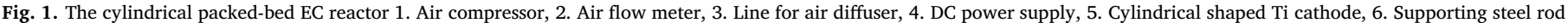
contact with Fe ball anodes, 7. Fe ball anodes put into inner cylindrical shaped Plexiglas, 8. Fe ball anodes.

oxidation of As(III) to As(V), which changes adsorption behavior and arsenic's toxicity [30]. The HFO has strong affinity for arsenic species as well as counter ions to cause chemical precipitation (Eq. (9)).
Therefore, arsenic is removed by mechanisms such as co-precipitation of iron arsenate (Eqs. (10)-(12)) and adsorption (Eqs. (13) and (14)). 
$2 \mathrm{H}_{2} \mathrm{O}+\mathrm{AsO}_{4}^{3-}+\mathrm{Fe}^{3+} \rightarrow \mathrm{FeAsO}_{4(\mathrm{~s})}+2 \mathrm{H}_{2} \mathrm{O}$

$\mathrm{nFe}_{\mathrm{x}}(\mathrm{OH})_{\mathrm{y}}^{(3 \mathrm{x}-\mathrm{y})}+$ As species $\rightarrow\left\{\left[\mathrm{Fe}_{\mathrm{x}}(\mathrm{OH})_{\mathrm{y}}^{(3 \mathrm{x}-\mathrm{y})}\right]_{\mathrm{n}} . \text { As species }\right\}_{(\mathrm{s})}$

$2 \mathrm{FeOOH}_{(\mathrm{s})}+\mathrm{H}_{2} \mathrm{AsO}_{4}^{-} \rightarrow(\mathrm{FeO})_{2} \mathrm{HAsO}_{4(\mathrm{~s})}+\mathrm{H}_{2} \mathrm{O}+\mathrm{OH}^{-}$

$3 \mathrm{FeOOH}+\mathrm{HAsO}_{4}^{2-} \rightarrow(\mathrm{FeO})_{3} \mathrm{AsO}_{4(\mathrm{~s})}^{-}+\mathrm{H}_{2} \mathrm{O}+2 \mathrm{OH}^{-}$

$\mathrm{FeOOH}_{(\mathrm{s})}+$ As species $\rightarrow[\mathrm{FeOOH}-$ As species $]$

$\mathrm{Fe}(\mathrm{OH})_{3(\mathrm{~s})}+\mathrm{AsO}_{4}^{3-} \rightarrow\left[\mathrm{Fe}(\mathrm{OH})_{3} \times \mathrm{AsO}_{4}^{3-}\right]_{(\mathrm{s})}$

\section{Results and discussion}

\subsection{Effect of initial $p H$}

The initial $\mathrm{pH}$ has a considerable influence on the performance of an electrocoagulation process [32]. Removal of arsenic from contaminated water is affected by its composition and chemistry. The speciation of As (V) in aqueous solution as a function of $\mathrm{pH}$ is $\mathrm{AsO}_{4}^{3-}$ at $\mathrm{pH}>12.4$; $\mathrm{HAsO}_{4}^{2-}$ at $7.2<\mathrm{pH}<12.4 ; \mathrm{H}_{2} \mathrm{AsO}_{4}^{-}$at $3.6<\mathrm{pH}<7.2$. The effect of the initial $\mathrm{pH}$ of groundwater in the range of 6.5-8.5 on As(III) and $\mathrm{As}(\mathrm{V})$ removals at different EC times $\left(t_{\mathrm{EC}}\right)$ was explored at the constant operating conditions because most of groundwaters containing arsenic have the $\mathrm{pH}$ in the range of 6-9 [32] (Fig. 2). As seen in Fig. 2(a), As(III) removal efficiencies and effluent concentrations $\left(C_{\mathrm{f}}<10 \mu \mathrm{g} / \mathrm{L}\right)$ were

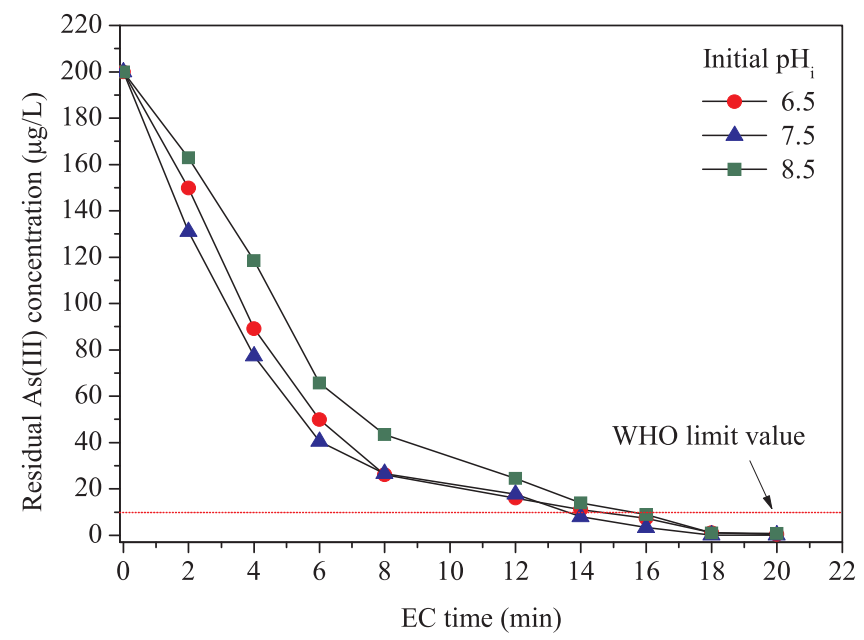

(a)

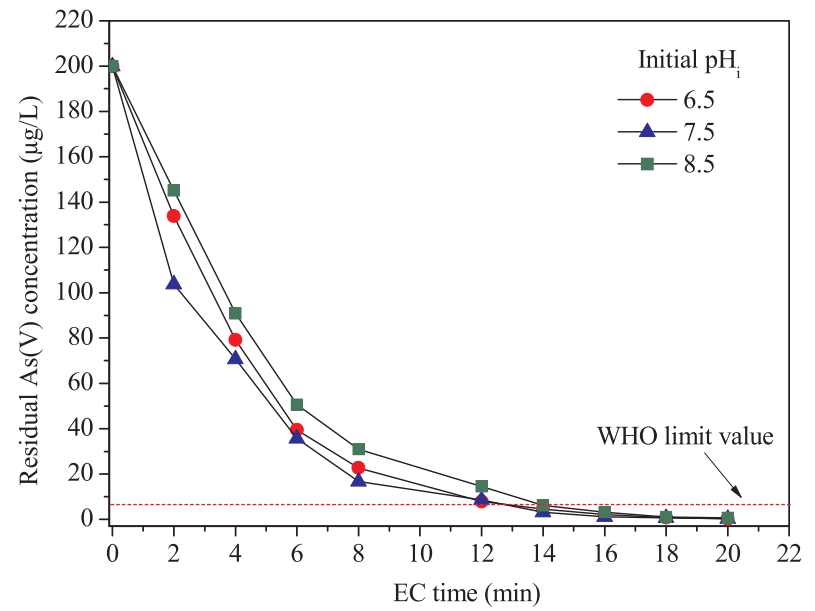

(b)

Fig. 2. Effect of initial $\mathrm{pH}$ on (a) $\mathrm{As}(\mathrm{III})$ and (b) $\mathrm{As}(\mathrm{V})$ removal efficiencies (Operating conditions: $\left.C_{\mathrm{o}}=200 \mu \mathrm{g} / \mathrm{L}, i=0.3 \mathrm{~A}, d_{\mathrm{p}}=7.5 \mathrm{~mm}, h=5 \mathrm{~cm}, Q_{\mathrm{air}}=6 \mathrm{~L} / \mathrm{min}\right)$. obtained as $99.8 \%$ and $0.40 \mu \mathrm{g} / \mathrm{L}$ at $20 \mathrm{~min}, 96.30 \%$ and $7.40 \mu \mathrm{g} / \mathrm{L}$ at $16 \mathrm{~min}$ for a $\mathrm{pH}_{\mathrm{i}}$ of $6.5,99.9 \%$ and $0.10 \mu \mathrm{g} / \mathrm{L}$ at $20 \mathrm{~min}, 96.0 \%$ and $8.01 \mu \mathrm{g} / \mathrm{L}$ at $14 \mathrm{~min}$ for a $\mathrm{pH}_{\mathrm{i}}$ of 7.5 , and $99.6 \%$ and $0.80 \mu \mathrm{g} / \mathrm{L}$ at $20 \mathrm{~min}, 95.6 \%$ and $8.9 \mu \mathrm{g} / \mathrm{L}$ at $16 \mathrm{~min}$ for a $\mathrm{pH}_{\mathrm{i}}$ of 8.5 , respectively. On the other hand, $A s(V)$ removal efficiencies along with the effluent concentrations in Fig. 2(b) were $99.9 \%$ and $0.20 \mu \mathrm{g} / \mathrm{L}$ at $20 \mathrm{~min}, 96.1 \%$ and $7.9 \mu \mathrm{g} / \mathrm{L}$ at $12 \mathrm{~min}$ for $\mathrm{a} \mathrm{pH}_{\mathrm{i}}$ of $6.5,99.9 \%$ and $0.30 \mu \mathrm{g} / \mathrm{L}$ at $20 \mathrm{~min}$, $95.8 \%$ and $8.50 \mu \mathrm{g} / \mathrm{L}$ at $12 \mathrm{~min}$ for $\mathrm{a} \mathrm{pH} \mathrm{H}_{\mathrm{i}}$ of 7.5 , and $99.7 \%$ and $0.60 \mu \mathrm{g}$ / $\mathrm{L}$ at $20 \mathrm{~min}, 96.9 \%$ and $6.3 \mu \mathrm{g} / \mathrm{L}$ at $14 \mathrm{~min}$ for a $\mathrm{pH}_{\mathrm{i}}$ of 8.5 .

According to the above results, the new $\mathrm{EC}$ reactor was able to remove arsenic species efficiently at $\mathrm{pH}_{\mathrm{i}}$ of 6.5-8.5, no significant effect was observed on the removal efficiency. The similar trend was observed by Kumar et al. [32] and they had removal efficiencies of As(III) and As (V) up to $97-99 \%$ in the $\mathrm{pH}_{\mathrm{i}}$ range 6-8. The removal efficiencies of arsenic in the studied $\mathrm{pH}$ range were $>96 \%$ at $14-16 \mathrm{~min}$ for As(III) and 12-14 min for $\mathrm{As}(\mathrm{V})$, which were consistent with the results reported earlier $[21,25]$. Therefore, the rest of experiments were carried out at its natural $\mathrm{pH}$ value (7.5). A slight increase in the $\mathrm{pH}_{\mathrm{i}}$ of $6.5,7.5$ and 8.5 resulted in final $\mathrm{pH}_{\mathrm{s}}\left(\mathrm{pH}_{\mathrm{f}}\right)$ of 7.2, 8.0 and 9.1 for As(III) removal and 7.2, 7.9 and 9.1 for $\mathrm{As}(\mathrm{V})$ removal after the EC process. Some researchers observed similar effect during the EC process and also reported that the EC can act as $\mathrm{pH}$ neutralization step [21,32]. The $\mathrm{pH}$ increase in the EC process was attributed to the formation of hydrogen gas and hydroxyl ions at the cathode according to Eqs. (4) and (5). Thus, the electrolytic cell was capable of producing enough hydroxides ions to compensate the acid-buffer and make the solution alkaline. In addition, a slight $\mathrm{pH}$ increase in the EC process may be expected because of sorption reactions of $\mathrm{As}(\mathrm{V})$ and $\mathrm{As}(\mathrm{III})$, which release hydroxyl ion groups from HFO surfaces as a result of ligand exchange [29-31,33]. The amount of electro-generated iron species increased with the increase in the operating time resulted in increase in the amount of flocs which was made up of insoluble monomeric and polymeric species, depending on redox conditions and $\mathrm{pH}$ of the aqueous medium. The species of metallic iron, depended on the final $\mathrm{pH}$ of the EC process, in turn precipitated as $\mathrm{Fe}(\mathrm{OH})_{2}$, a variety of $\mathrm{Fe}(\mathrm{II} / \mathrm{III})$ (oxy)(hydro)oxides and $\mathrm{Fe}(\mathrm{OH})_{3}$ [34]. These HFO have strong affinity for arsenic species as well as counter ions to cause adsorption, precipitation and co-precipitation reactions (Eqs. (9)-(14)).

Amount of Fe dissolved at the anode in the EC process is expressed with the Faraday's law (Eq. (15)), which depends on the EC time $\left(t_{\mathrm{EC}}\right)$ and applied current (i). In this case, the increasing current and EC time in the EC process caused an increase in the amount of dissolved coagulant from the anode $\left(C_{\text {electrode }}\right)$ :

$C_{\text {electrode }}=\left(i \times t_{\mathrm{EC}} \times M_{\mathrm{Fe}}\right) /(z \times F)$

where $M_{\mathrm{Fe}}(55.85 \mathrm{~g} / \mathrm{mol})$ is the molecular weight, $i$ is applied current (A), $t_{\mathrm{EC}}$ is required the EC time (min), $z$ is the number of electrons involved in the oxidation/reduction reaction $\left(z_{\mathrm{Fe}}=2\right)$ and $F$ is the Faraday's constant $(96,487 \mathrm{C})$. Amounts of the dissolved $\mathrm{Fe}$ in the $\mathrm{pH}_{\mathrm{i}}$ range of $6.5,7.5$ and 8.5 at the optimum conditions were 0.0909 , 0.0752 and $0.0875 \mathrm{~g}$ for $\mathrm{As}(\mathrm{III})$ removal, and $0.0650,0.0628$, and $0.0751 \mathrm{~g}$ for $\mathrm{As}(\mathrm{V})$ removal, respectively. The current efficiency (CE $\left.(\%)=\left(C_{\text {exp }} / C_{\text {theo }}\right) \times 100\right)$ is defined as the ratio of the actual electrode consumption to the theoretical value. It is also an important parameter for the EC process because it affects the lifetime of the electrodes. Because of the electrochemical side-reactions, the experimental (or actual) electrode consumption may be reduced or increased from this theoretical value depending upon the groundwater characteristics in the EC reactor and operational conditions [33]. Current efficiencies at $\mathrm{pH}_{\mathrm{i}} 6.5$, 7.5 and 8.5 in the EC process were calculated as $109.0 \%, 103.1 \%$ and $105.0 \%$ for As(III) removal, and $104.0 \%, 100.4 \%$ and $103.1 \%$ for As(V) removal.

In conventional chemical coagulation, the arsenic removal efficiency improved with an increase of dosages of coagulants such as $\mathrm{FeCl}_{3}$ and alum. Similarly, the arsenic removal in the EC process depended on the amount of coagulant generated or the applied charge as the applied 
charge is directly proportional to the amount of coagulant generated. Actually, the charge loading $\left(q=i \times t_{\mathrm{EC}}\right)$ rather than current density affects the treatment efficiency. The required charge loadings for $C_{\mathrm{f}}<10 \mu \mathrm{g} / \mathrm{L}$ at $\mathrm{pH}_{\mathrm{i}} 6.5,7.5$ and 8.5 were determined to be 288,252 and $288 \mathrm{C}$ for As(III) removal and 216, 216 and 252C for As(V) removal, respectively. In this case, the arsenic removal capacity $(R C)$ as removed $\mu \mathrm{g}$ As per $\mathrm{C}$ or $\mathrm{mg} \mathrm{Fe}$ is calculated from the following equation (Eq. (16))

$R C=\left[\left(C_{\mathrm{o}}-C_{\mathrm{t}}\right) \times v\right] / q$ or $R C=\left[\left(C_{\mathrm{o}}-C_{\mathrm{t}}\right) \times v\right] / C_{\mathrm{Fe}}$

where $v$ is solution volume in the EC reactor, $q$ is charge loading (Coulomb), and $C_{\mathrm{o}}$ and $C_{\mathrm{t}}$ are initial and at time $t$ arsenic concentrations $(\mu \mathrm{g} / \mathrm{L})$ in solution. $R C$ values for $\mathrm{pH}_{\mathrm{i}}$ of $6.5,7.5$ and 8.5 were $2.12 \mu \mathrm{g} /$ $\mathrm{mg}(0.671 \mu \mathrm{g} / \mathrm{C}), 2.55 \mu \mathrm{g} / \mathrm{mg}(0.762 \mu \mathrm{g} / \mathrm{C})$ and $2.18 \mu \mathrm{g} / \mathrm{mg}(0.664 \mu \mathrm{g} /$ C) for $\mathrm{As}(\mathrm{III}) \mathrm{removal}$, and $2.96 \mu \mathrm{g} / \mathrm{mg}(0.891 \mu \mathrm{g} / \mathrm{C}), 3.05 \mu \mathrm{g} / \mathrm{mg}$ $(0.889 \mu \mathrm{g} / \mathrm{C})$ and $2.58 \mu \mathrm{g} / \mathrm{mg}(0.769 \mu \mathrm{g} / \mathrm{C})$ for $\mathrm{As}(\mathrm{V})$ removal, respectively. Amounts of sludge at the optimum the EC times for $\mathrm{pH}_{\mathrm{i}}$ of 6.5 , 7.5 and 8.5 were calculated as $0.133,0.139$ and $0.129 \mathrm{~kg} / \mathrm{m}^{3}$ for As(III) removal and $0.126,0.144$ and $0.1351 \mathrm{~kg} / \mathrm{m}^{3}$ for $\mathrm{As}(\mathrm{V})$ removal.

\subsection{Effect of applied current}

In electrochemical processes, current and EC time are the most important parameters for controlling the reaction rate in the reactor. Current determines not only the coagulant dosage but also the mixing rate within the EC process [21,26,34-37]. The EC time determines the rate of dissolution of iron ions $\left(\mathrm{Fe}^{2+}\right.$ and $\mathrm{Fe}^{3+}$ ), as it strongly depends on the applied current value. Fig. 3 illustrates effect of the applied current on the residual arsenic concentration as a function of $t_{\mathrm{EC}}$. As seen in Fig. 3 , the $t_{\mathrm{EC}}$ required to meet effluent arsenic concentration of $<10 \mu \mathrm{g} / \mathrm{L}$ reduced with increase in the applied current. The obtained effluent As concentrations and operating times for As(III) removal were $11.5 \mu \mathrm{g} / \mathrm{L}$ and $>20 \mathrm{~min}$ at $0.075 \mathrm{~A}, 9.02 \mu \mathrm{g} / \mathrm{L}$ and $16 \mathrm{~min}$ at $0.15 \mathrm{~A}$, and $8.01 \mu \mathrm{g} / \mathrm{L}$ and $14 \mathrm{~min}$ at $0.30 \mathrm{~A}$, respectively. Values of $C_{\mathrm{f}}$ and $t_{\mathrm{EC}}$ for $\mathrm{As}(\mathrm{V})$ removal were $9.09 \mu \mathrm{g} / \mathrm{L}$ and $18 \mathrm{~min}$ at $0.075 \mathrm{~A}$, $7.70 \mu \mathrm{g} / \mathrm{L}$ and $16 \mathrm{~min}$ at $0.15 \mathrm{~A}$, and $8.50 \mu \mathrm{g} / \mathrm{L}$ and $12 \mathrm{~min}$ at $0.30 \mathrm{~A}$, respectively.

According to the Faraday's law, whenever 1 Faraday of charge passes through the circuit, $28 \mathrm{~g}$ of iron are dissolved at Fe anode in the EC process. When the charge loading of the EC was low, the coagulant dosages were not sufficient to remove arsenic ions, and thus the arsenic removal efficiency was not high [33]. The minimum required charge loadings for effluent arsenic concentration of $<10 \mu \mathrm{g} / \mathrm{L}$ in the EC using Fe ball anodes were obtained as 90, 144 and 252C for As(III) removal, 81, 144 and 216C for $\mathrm{As}(\mathrm{V})$ removal. Amount of iron dosages both theoretically $\left(C_{\text {theo }}\right)$ and experimentally $\left(C_{\text {exp }}\right)$ along with current efficiency (Eq. (15)) were calculated as $0.0261 \mathrm{~g}, 0.0281 \mathrm{~g}$ and $108.0 \%$ at $0.075 \mathrm{~A} ; 0.0417 \mathrm{~g}, 0.0433 \mathrm{~g}$ and $104.0 \%$ at $0.15 \mathrm{~A}$; and $0.0729 \mathrm{~g}$, $0.0752 \mathrm{~g}$ and $103.1 \%$ at $0.30 \mathrm{~A}$ for As(III) removal, and $0.0234 \mathrm{~g}$, $0.0244 \mathrm{~g}$ and $104.0 \%$ at $0.075 \mathrm{~A} ; 0.0421 \mathrm{~g}, 0.0417 \mathrm{~g}$ and $101.0 \%$ at $0.15 \mathrm{~A}$; and $0.0625 \mathrm{~g}, 0.0628 \mathrm{~g}$ and $100.4 \%$ at $0.30 \mathrm{~A}$ for $\mathrm{As}(\mathrm{V})$ removal. It can be concluded from the results that the coagulant dosage increased with respect to increase in current to achieve the required effluent concentration of arsenic during the removal. Amount of removed As per mg Fe or $\mathrm{C}$ for $\mathrm{As}(\mathrm{III})$ and $\mathrm{As}(\mathrm{V})$ were also determined to be $6.70 \mu \mathrm{g} / \mathrm{mg}(2.10 \mu \mathrm{g} / \mathrm{C})$ and $7.83 \mu \mathrm{g} / \mathrm{mg}(2.36 \mu \mathrm{g} / \mathrm{C})$ at $0.075 \mathrm{~A}$, $4.40 \mu \mathrm{g} / \mathrm{mg}(1.33 \mu \mathrm{g} / \mathrm{C})$ and $4.57 \mu \mathrm{g} / \mathrm{mg}(1.34 \mu \mathrm{g} / \mathrm{C})$ at $0.15 \mathrm{~A}$, and $2.55 \mu \mathrm{g} / \mathrm{mg}(0.762 \mu \mathrm{g} / \mathrm{C})$ and $3.05 \mu \mathrm{g} / \mathrm{mg}(0.889 \mu \mathrm{g} / \mathrm{C})$ at $0.30 \mathrm{~A}$, respectively.

In this preliminary investigation, the operating cost of the treated arsenic removal can be calculated by considering two parameters as major cost items namely, the amounts of energy $\left(C_{\text {energy }}\right)$ and electrode consumptions in the EC process [21]. According to the Turkish market in December 2016, prices for electrical energy $(\alpha)$ and Fe ball electrode $(\beta)$ were $0.190 \$ / \mathrm{kWh}$ and $4.50 \$ / \mathrm{kg}$, respectively. The operating cost

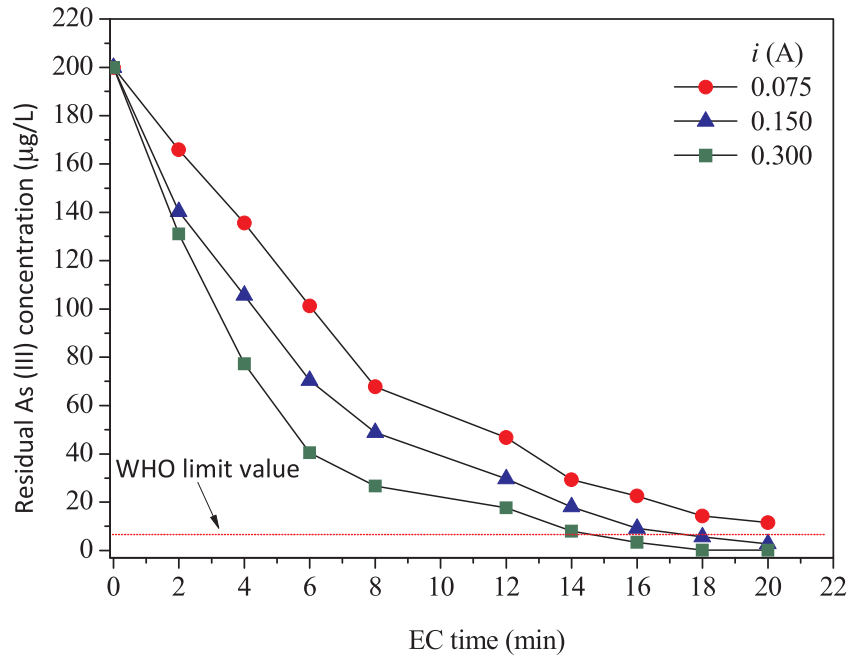

(a)

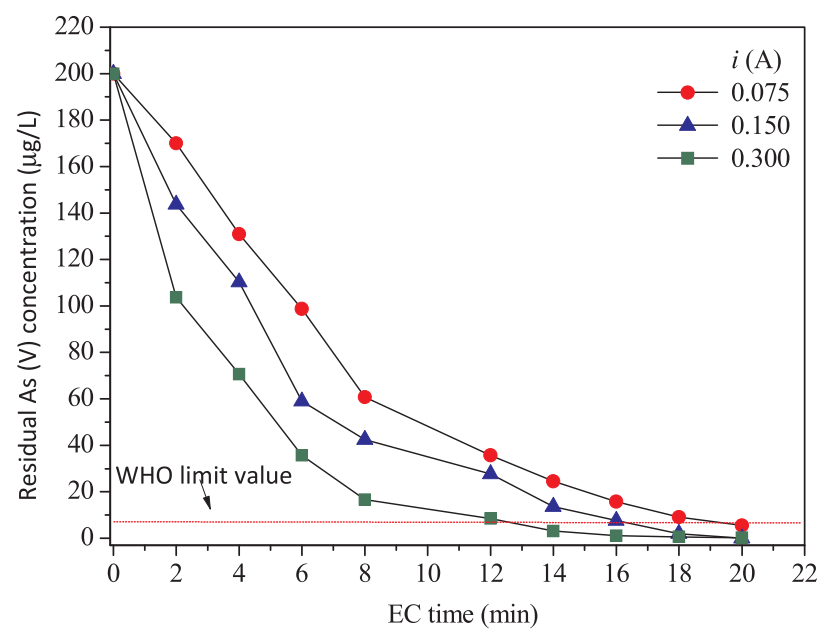

(b)

Fig. 3. Effect of applied current on (a) As(III) (b) $\mathrm{As}(\mathrm{V})$ removal efficiencies (Operating conditions: $C_{\mathrm{o}}$ of 200 , a $\mathrm{pH}_{\mathrm{i}}$ of $7.5, d_{\mathrm{p}}$ of $7.5 \mathrm{~mm}, h$ of $5 \mathrm{~cm}, Q_{\text {air }}$ of $6 \mathrm{~L} / \mathrm{min}$ ).

for the EC process was calculated with the following equation

$O C=\alpha \times C_{\text {energy }}+\beta \times C_{\text {electrode }}$

The following equation was used to calculate $C_{\text {energy }}$

$C_{\text {energy }}=\frac{i \times t_{\mathrm{EC}} \times U}{v}$

where $U$ is cell voltage $(\mathrm{V})$ and $v$ is the volume $\left(\mathrm{m}^{3}\right)$ of wastewater $(1 \mathrm{~L})$. The operating cost $(O C)$ for $\mathrm{As}(\mathrm{III})$ and $\mathrm{As}(\mathrm{V})$ removals were also calculated as 0.737 and $0.530 \$ / \mathrm{m}^{3}$ for a $\mathrm{pH}_{\mathrm{i}}$ of $6.5,0.612$ and $0.546 \$ / \mathrm{m}^{3}$ for a $\mathrm{pH}_{\mathrm{i}}$ of 7.5 , and 0.734 and $0.632 \$ / \mathrm{m}^{3}$ for a $\mathrm{pH}_{\mathrm{i}}$ of 8.5 , respectively. From Equations of (15), (17) and (18), energy and electrode consumptions and operating cost at $0.075-0.3 \mathrm{~A}$ for $\mathrm{As}(\mathrm{III})$ removal were calculated as $0.530 \mathrm{kWh} / \mathrm{m}^{3}, \quad 0.0281 \mathrm{~kg} / \mathrm{m}^{3}$ and $0.227 \$ / \mathrm{m}^{3}$ for $0.075 \mathrm{~A}, 0.904 \mathrm{kWh} / \mathrm{m}^{3}, 0.0433 \mathrm{~kg} / \mathrm{m}^{3}$ and $0.367 \$ / \mathrm{m}^{3}$ for $0.15 \mathrm{~A}$, and $1.442 \mathrm{kWh} / \mathrm{m}^{3}, 0.0752 \mathrm{~kg} / \mathrm{m}^{3}$ and $0.612 \$ / \mathrm{m}^{3}$ for $0.30 \mathrm{~A}$, respectively. On the other hand, $C_{\text {energy }}, C_{\text {electrode }}$ and $O C$ for $\mathrm{As}(\mathrm{V})$ removal at $0.075-0.3 \mathrm{~A}$ were $0.502 \mathrm{kWh} / \mathrm{m}^{3}, 0.0244 \mathrm{~kg} / \mathrm{m}^{3}$ and $0.205 \$ / \mathrm{m}^{3}$ for $0.075 \mathrm{~A}, 0.872 \mathrm{kWh} / \mathrm{m}^{3}, 0.0421 \mathrm{~kg} / \mathrm{m}^{3}$ and $0.355 \$ / \mathrm{m}^{3}$ for $0.15 \mathrm{~A}$, and $1.386 \mathrm{kWh} / \mathrm{m}^{3}, 0.0628 \mathrm{~kg} / \mathrm{m}^{3}$ and $0.546 \$ / \mathrm{m}^{3}$ for $0.30 \mathrm{~A}$, respectively. The amounts of sludge were calculated for the currents of $0.075,0.15$ and $0.30 \mathrm{~A}$ as $0.112,0.139$ and $0.124 \mathrm{~kg} / \mathrm{m}^{3}$ for As(III) removal and $0.126,0.144$ and $0.128 \mathrm{~kg} / \mathrm{m}^{3}$ for $\mathrm{As}(\mathrm{V})$ removal. According to the 


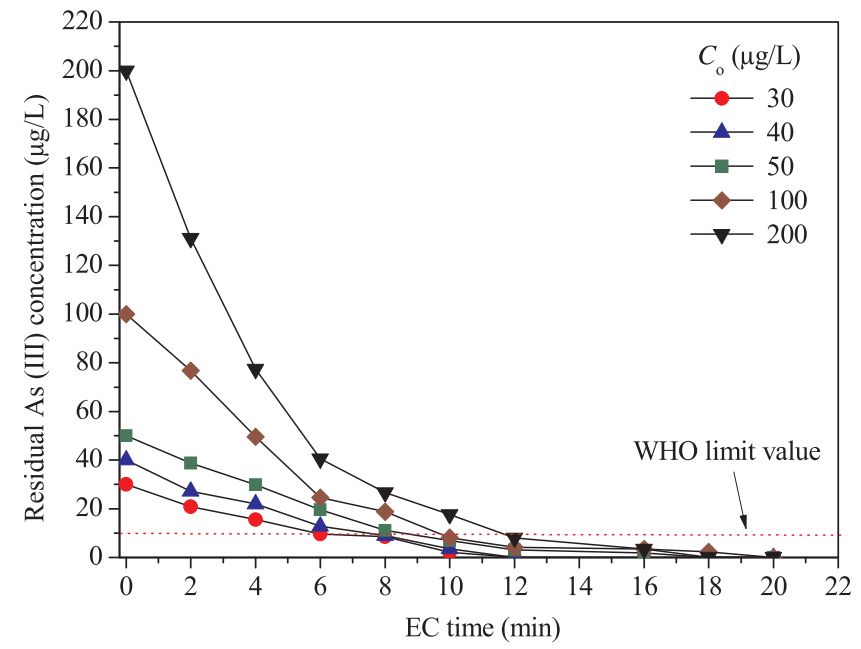

(a)

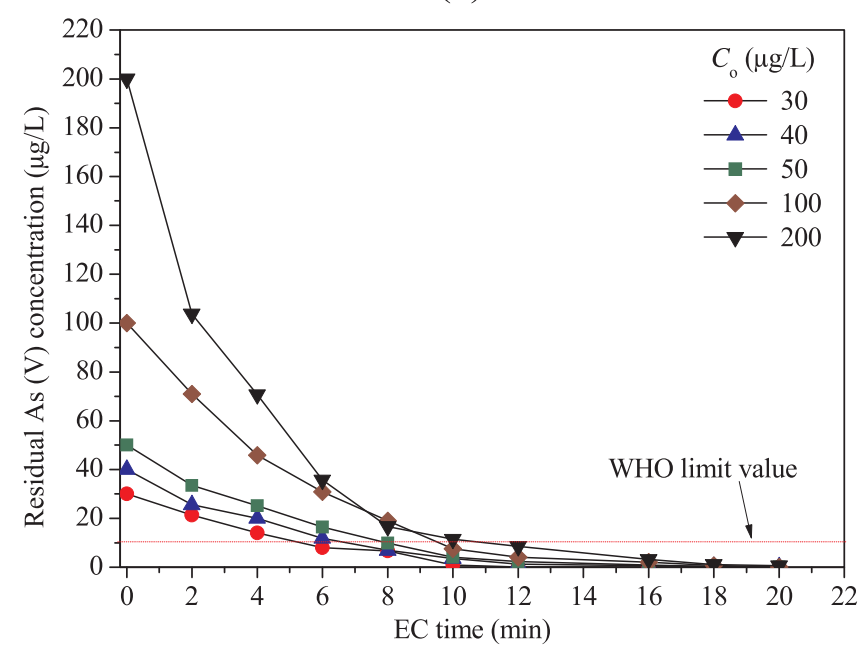

(b)

Fig. 4. Effect of arsenic concentration on (a) As(III) and (b) $A s(V)$ removal efficiencies (Operating conditions: a $\mathrm{pH}_{\mathrm{i}}$ of 7.5, $0.10 \mathrm{~A}, d_{\mathrm{p}}$ of $5 \mathrm{~mm}, h$ of $5 \mathrm{~cm}, Q_{\text {air }}$ of $6 \mathrm{~L} / \mathrm{min}$ ).

results, as $i$ and $t_{\mathrm{EC}}$ time increased, energy and electrode consumptions increased. $O C$ of $\mathrm{As}(\mathrm{III})$ removal was less than that of $\mathrm{As}(\mathrm{V})$ removal. The retention time of groundwater containing arsenic in the EC reactor was also important since the increase in the applied current decreased the groundwater retention time which could reduce the EC reactor volume. Therefore, $0.30 \mathrm{~A}$ was chosen as the optimum current value for the rest of experiments.

\subsection{Effect of arsenic concentration}

The arsenic removal in the EC process at initial concentrations of $30-200 \mu \mathrm{g} / \mathrm{L}$ with respect to residual arsenic concentrations vs EC time is shown in Fig. 4. As seen in Fig. 4, As(III) and As(V) removal efficiencies decreased with increase in arsenic concentrations from 30 to $200 \mu \mathrm{g} / \mathrm{L}$ while its removal efficiency increased with increase in the EC time. The obtained effluent arsenic concentrations and EC times for As (III) and $\mathrm{As}(\mathrm{V})$ removals from the groundwater were 9.62 and $8.03 \mu \mathrm{g} / \mathrm{L}$ at $6 \mathrm{~min}$ for $30 \mu \mathrm{g} / \mathrm{L}, 8.99$ and $6.90 \mu \mathrm{g} / \mathrm{L}$ at $8 \mathrm{~min}$ for $40 \mu \mathrm{g} / \mathrm{L}, 6.87 \mu \mathrm{g} /$ $\mathrm{L}$ at $10 \mathrm{~min}$ and $9.87 \mu \mathrm{g} / \mathrm{L}$ at $8 \mathrm{~min}$ for $50 \mu \mathrm{g} / \mathrm{L}, 8.20$ and $7.50 \mu \mathrm{g} / \mathrm{L}$ at $10 \mathrm{~min}$ for $100 \mu \mathrm{g} / \mathrm{L}, 8.01 \mu \mathrm{g} / \mathrm{L}$ at $14 \mathrm{~min}$ and $8.50 \mu \mathrm{g} / \mathrm{L}$ at $12 \mathrm{~min}$ for $200 \mu \mathrm{g} / \mathrm{L}$, respectively. The results from these experiments showed that the effluent $\mathrm{As}(\mathrm{III})$ and $\mathrm{As}(\mathrm{V})$ concentrations decreased significantly with increase in initial concentration of arsenic from 30 to $200 \mu \mathrm{g} / \mathrm{L}$. In addition, it was clear that the rate of removal was sharp at the beginning of the EC process (between 0 and $6 \mathrm{~min}$ ), and afterwards the slope of the curve decreased. At the beginning (i.e., lag stage) of the EC process, the amount of iron produced electrochemically at especially high $\mathrm{As}(\mathrm{III})$ and $\mathrm{As}(\mathrm{V})$ concentrations would be quite less to cause decrease in concentration in the groundwater. However, amount of coagulant (hydrous ferric oxides) produced in the EC process was increased with the increase in the EC time which led to decrease in the effluent arsenic concentration and arsenic was adsorbed on it. The curves were nearly the same at the end of experiment since abundance of hydrous ferric oxides occurred at the end of the process (Fig. 4). Higher removal efficiency at low $C_{\mathrm{o}}, t_{\mathrm{EC}}(2-8 \mathrm{~min})$ and constant applied current observed as compared to high $C_{\mathrm{o}}$.

Values of electrode consumption and $C E$ for 30, 40, 50, 100 and $200 \mu \mathrm{g} / \mathrm{L}$ at the permissible effluent concentration of $<10 \mu \mathrm{g} / \mathrm{L}$ in the EC process were calculated as $0.0331 \mathrm{~g}$ and $106 \%, 0.0433 \mathrm{~g}$ and $104 \%$, $0.0533 \mathrm{~g}$ and $102 \%, 0.0531 \mathrm{~g}$ and $102.0 \%$, and $0.0752 \mathrm{~g}$ and $103.1 \%$ for As(III) removal, $0.0322 \mathrm{~g}$ and $103.0 \%, 0.0417 \mathrm{~g}$ and $104.0 \%$, $0.0417 \mathrm{~g}$ and $101.0 \%, 0.0521 \mathrm{~g}$ and $104.0 \%$, and $0.0625 \mathrm{~g}$ and $100.4 \%$ for As(V) removal, respectively. The required minimum charge loadings for $30,50,100$ and $200 \mu \mathrm{g} / \mathrm{L}$ were determined as 108, 144, 180, 180, and 252C for As(III) removal, and 108, 144, 144, 180 and 216C for As (V) removal. The amounts of removed As per mg Fe or C for As(III) and $\mathrm{As}(\mathrm{V})$ removals were calculated as $5.746 \mu \mathrm{g} / \mathrm{mg}(1.763 \mu \mathrm{g} / \mathrm{C})$ and $5.963 \mu \mathrm{g} / \mathrm{mg}(1.778 \mu \mathrm{g} / \mathrm{C})$ for $\mu \mathrm{g} / \mathrm{L}, 4.407 \mu \mathrm{g} / \mathrm{mg}(1.327 \mu \mathrm{g} / \mathrm{C})$ and $4.409 \mu \mathrm{g} / \mathrm{mg}(1.327 \mu \mathrm{g} / \mathrm{C})$ for $40 \mu \mathrm{g} / \mathrm{L}, 3.635 \mu \mathrm{g} / \mathrm{mg}(1.073 \mu \mathrm{g} / \mathrm{C})$ and $4.517 \mu \mathrm{g} / \mathrm{mg}(1.320 \mu \mathrm{g} / \mathrm{C})$ for $50 \mu \mathrm{g} / \mathrm{L}, 3.610 \mu \mathrm{g} / \mathrm{mg}(1.066 \mu \mathrm{g} / \mathrm{C})$ and $3.553 \mu \mathrm{g} / \mathrm{mg}(1.069 \mu \mathrm{g} / \mathrm{C})$ for $100 \mu \mathrm{g} / \mathrm{L}$, and $2.553 \mu \mathrm{g} / \mathrm{mg}(0.762 \mu \mathrm{g} / \mathrm{C})$ and $3.051 \mu \mathrm{g} / \mathrm{mg}(0.887 \mu \mathrm{g} / \mathrm{C})$ for $200 \mu \mathrm{g} / \mathrm{L}$, respectively. These results indicated that as the initial concentration of arsenic increased, the EC time increased. The amount of sludge at the optimum EC times for 30, 40, 50, 100 and $200 \mu \mathrm{g} / \mathrm{L}$ were calculated as 0.062, 0.084, 0.0981, 0.1052 , and $0.0 .124 \mathrm{~kg} / \mathrm{m}^{3}$ for As(III) removal and $0.065,0.088$, $0.1002,0.115$, and $0.128 \mathrm{~kg} / \mathrm{m}^{3}$ for $\mathrm{As}(\mathrm{V})$ removal, respectively.

\subsection{Effect of airflow rate}

Introduction of air or oxygen in the EC process was necessary to assure oxidation of electrochemically dissolved $\mathrm{Fe}^{2+}$ from the anodes [38]. Moreover, the effect of air bubbling not only oxidizes $\mathrm{Fe}^{2+}$ to $\mathrm{Fe}^{3+}$ but also promotes the coagulation/flocculation process due to the movement in the solution in the EC reactor. Then, removals of As(III) and $\mathrm{As}(\mathrm{V})$ ions were governed by adsorption/complexation with iron hydroxides generated in the process. At same time, formation and growth of passivation layer (like metal (oxy)hydroxides precipitates) on the anode surfaces didn't occur due to the turbulent (or mixing) behavior of the airflow in EC reactor. Some researches [26,32,34,39] reported that As(III) removal mechanism in the EC with iron electrodes was oxidation of $\mathrm{As}(\mathrm{III})$ to $\mathrm{As}(\mathrm{V})$ and surface complexation with iron hydroxides. The standard potential of the oxidation of $\mathrm{As}(\mathrm{III})$ to $\mathrm{As}(\mathrm{V})$ is $+0.56 \mathrm{~V}$, which is lower than the oxidation potential of Fe(II) to Fe(III) and other species typically found in groundwater. Although Fe(II) oxidation occurred rapidly in the presence of air, the oxidation rate of As(III) is extremely slow. It was reported that As(III) was only slowly oxidized by dissolved $\mathrm{O}_{2}$ at $\mathrm{pH}$ 7.6-8.5 although $\mathrm{As}(\mathrm{V})$ was thermodynamically favored under oxidizing conditions [40].

The effect of air flow rate $\left(Q_{\text {air }}\right)$ at $0-6 \mathrm{~L} / \mathrm{min}$ was investigated with respect to the effluent arsenic concentration and EC time in the EC process using Fe ball anodes (Figs. 5 and 6). The effluent arsenic concentrations for $\mathrm{As}(\mathrm{III})$ and $\mathrm{As}(\mathrm{V})$ removals decreased with the increase in both air flow rate and shorter EC time. As seen in Fig. 5, the effluent arsenic concentration with no airflow present for As(III) and As(V) removals reduced to $7.80 \mu \mathrm{g} / \mathrm{L}$ at $20 \mathrm{~min}$ and $9.03 \mu \mathrm{g} / \mathrm{L}$ at $18 \mathrm{~min}$. When the air was present in the EC reactor, the residual arsenic concentration for $\mathrm{As}(\mathrm{III})$ and $\mathrm{As}(\mathrm{V})$ removals were $9.02 \mu \mathrm{g} / \mathrm{L}$ and $4.90 \mu \mathrm{g} / \mathrm{L}$ at $16 \mathrm{~min}$ for $2 \mathrm{~L} / \mathrm{min}$, and $8.01 \mu \mathrm{g} / \mathrm{L}$ at $14 \mathrm{~min}$ and $8.5 \mu \mathrm{g} / \mathrm{L}$ at $12 \mathrm{~min}$ for $6 \mathrm{~L} /$ min, respectively. In this case, the required charge loadings for $Q_{\text {air }}$ of 0 , 


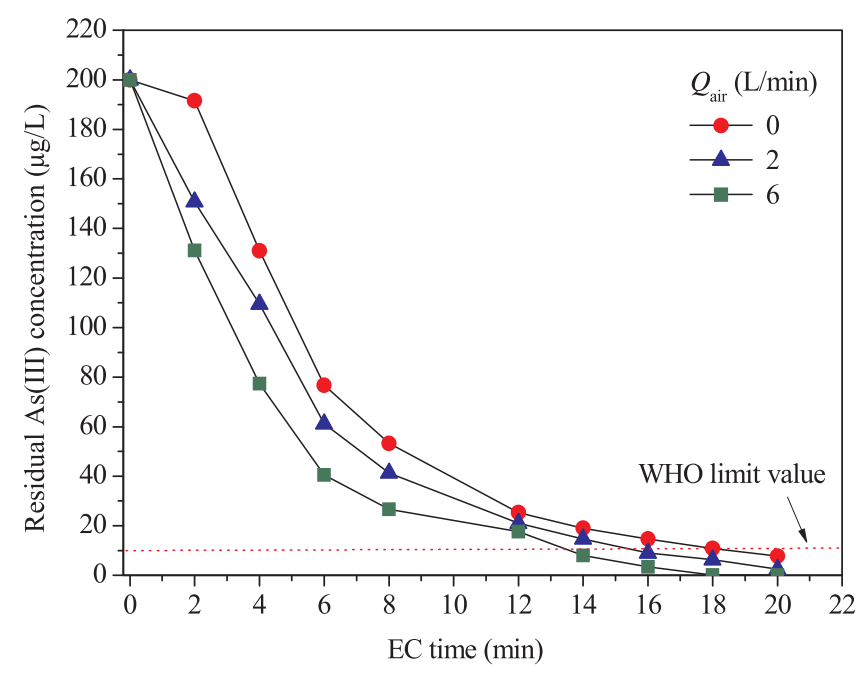

(a)

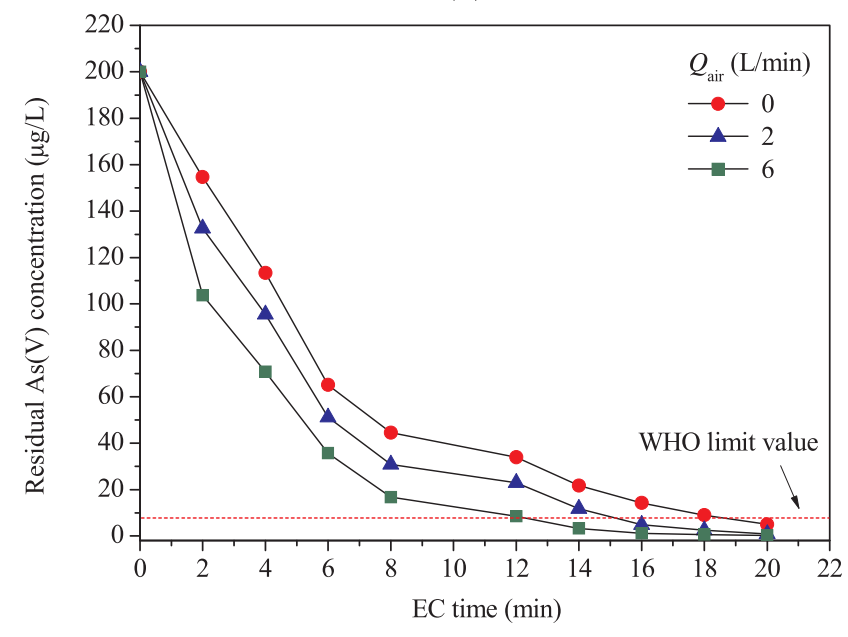

(b)

Fig. 5. Effect of airflow on (a) As(III) and (b) $A s(V)$ removal efficiencies (Operating conditions: $\mathrm{pH}_{\mathrm{i}}=7.5, i=0.30 \mathrm{~A}, C_{\mathrm{o}}=200 \mu \mathrm{g} / \mathrm{L}, d_{\mathrm{p}}=7.5 \mathrm{~mm}, h=5 \mathrm{~mm}$ ).

2 and $6 \mathrm{~L} / \mathrm{min}$ were calculated as 360,288 and $252 \mathrm{C}$ for As(III) removal and 324, 288 and 216C for As(V) removal. Experimentally dissolved Fe dosage for As(III) and As(V) removals were obtained as $0.110 \mathrm{~g}$ (CE of $106.0 \%)$ and $0.0966 \mathrm{~g}(C E$ of $103.0 \%)$ for $Q_{\text {air }}$ of $0 \mathrm{~L} / \mathrm{min}, 0.0859 \mathrm{~g}(C E$ of $103.0 \%$ ) and $0.0875 \mathrm{~g}(C E$ of $105.0 \%)$ for $Q_{\text {air }}$ of $2 \mathrm{~L} / \mathrm{min}$, and $0.0752 \mathrm{~g}$ (CE of $100.4 \%$ ) and 0.0628 (CE of $100.3 \%$ ) for $Q_{\text {air }}$ of $6 \mathrm{~L} / \mathrm{min}$, respectively. In addition, removed arsenic per mg Fe for As(III) and As (V) removals were calculated as $1.740 \mu \mathrm{g} / \mathrm{mg}$ and $1.977 \mu \mathrm{g} / \mathrm{mg}$ for $Q_{\text {air }}$ of $0 \mathrm{~L} / \mathrm{min}, 2.225 \mu \mathrm{g} / \mathrm{mg}$ and $2.229 \mu \mathrm{g} / \mathrm{mg}$ for $Q_{\text {air }}$ of $2 \mathrm{~L} / \mathrm{min}$, and $2.553 \mu \mathrm{g} / \mathrm{mg}$ and $3.051 \mu \mathrm{g} / \mathrm{mg}$ for $Q_{\text {air }}$ of $6 \mathrm{~L} / \mathrm{min}$, respectively.

In general, oxygen concentration in natural groundwaters is low, but value of dissolved oxygen (DO) in surface water is high. In the case of As(III) removal from the groundwater, values of DO increased from 7.2 to $8.1 \mathrm{mg} / \mathrm{L}$ with the increase in values of $Q_{\text {air }}$ from 0 to $6 \mathrm{~L} / \mathrm{min}$ at 20 min whereas the value of DO without air decreased from 7.2 to $3.1 \mathrm{mg} / \mathrm{L}$ at the same operating time. However, the arsenic removal efficiency increased with increase in oxidation of $\mathrm{Fe}^{2+}$ to $\mathrm{Fe}^{3+}$ and homogeneous mixture within the EC reactor. Concentrations of DO increased with increase in flow rate as compared to no $Q_{\text {air }}$. The results indicated that the operating time needed for the permissible WHO limit value reduced as the $Q_{\mathrm{air}}$ increased in the range of $0-6 \mathrm{~L} / \mathrm{min}$.

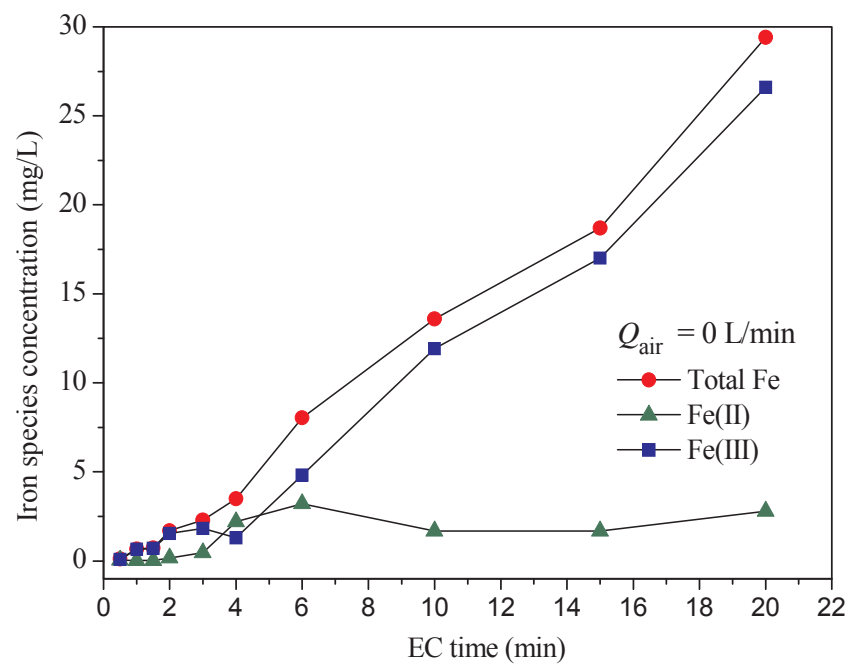

(a)

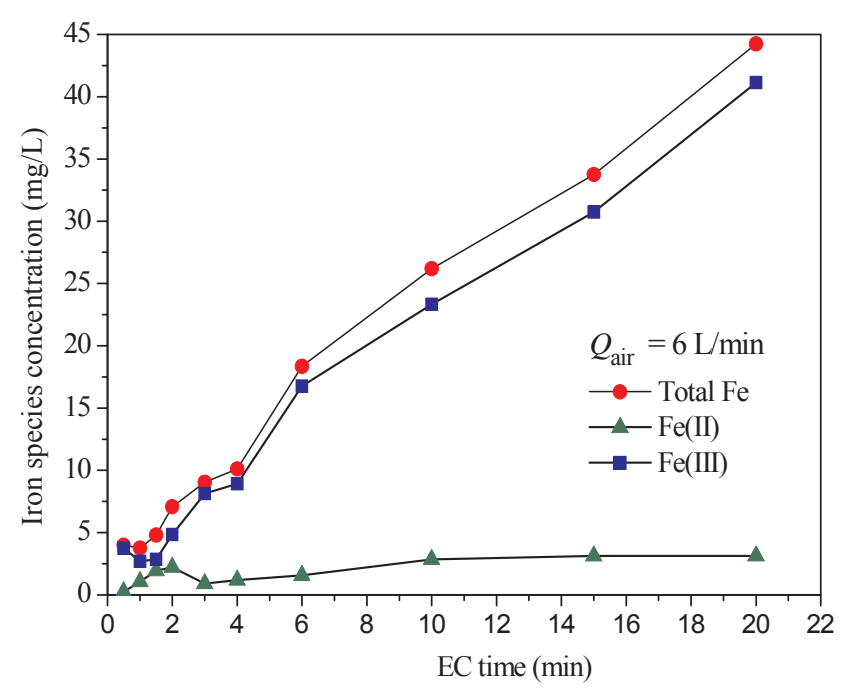

(b)

Fig. 6. The effect of air flow rate on iron species generated during EC process (Operating conditions: $C_{\mathrm{o}}=200 \mu \mathrm{g} / \mathrm{L}, i=0.30 \mathrm{~A}, d_{\mathrm{p}}=7.5 \mathrm{~mm}, h=5 \mathrm{~cm}$ ).

\subsection{Effect of diameter of Fe ball anode}

Diameter of Fe ball anode $\left(d_{\mathrm{p}}\right)$ in the EC process is an important operating parameter which influences the arsenic removal efficiency. As diameter of Fe ball anode in the reactor increases at a constant anode height in the reactor, the total surface area of anodes used in the reactor decreases. The experiments were conducted at varying diameters of iron ball anodes from 5 to $10 \mathrm{~mm}$ in the fixed-bed EC reactor at the constant operating conditions. Fig. 7 shows the influence of diameter of Fe ball anodes on the As(III) and As(V) removals. As seen in Fig. 7, the effluent arsenic concentrations at 5.0, 7.5 and $10 \mathrm{~mm}$ of Fe ball anodes were $7.10 \mu \mathrm{g} / \mathrm{L}$ and $14 \mathrm{~min}, 8.01 \mu \mathrm{g} / \mathrm{L}$ and $14 \mathrm{~min}, 6.60 \mu \mathrm{g} / \mathrm{L}$ and $16 \mathrm{~min}$ for As(III) removal, and 7.50 $\mathrm{gg} / \mathrm{L}$ and $12 \mathrm{~min}, 8.50 \mu \mathrm{g} / \mathrm{L}$ and $12 \mathrm{~min}, 7.90 \mu \mathrm{g} / \mathrm{L}$ and $14 \mathrm{~min}$ for $\mathrm{As}(\mathrm{V})$ removal, respectively.

The charge loading values for effluent concentration of $<10 \mu \mathrm{g} / \mathrm{L}$ at 5.0, 7.5 and $10 \mathrm{~mm}$ were calculated as 252, 252, and $288 \mathrm{C}$ for As(III) removal and 216, 216, and 252C for $\mathrm{As}(\mathrm{V})$ removal, respectively. The charge loadings for both $\mathrm{As}(\mathrm{III})$ and $\mathrm{As}(\mathrm{V})$ increased with increasing diameter of $\mathrm{Fe}$ ball anodes. Total surface area of Fe ball anodes at constant height of $5 \mathrm{~cm}$ and $0.3 \mathrm{~A}$ in the EC reactor were obtained as 

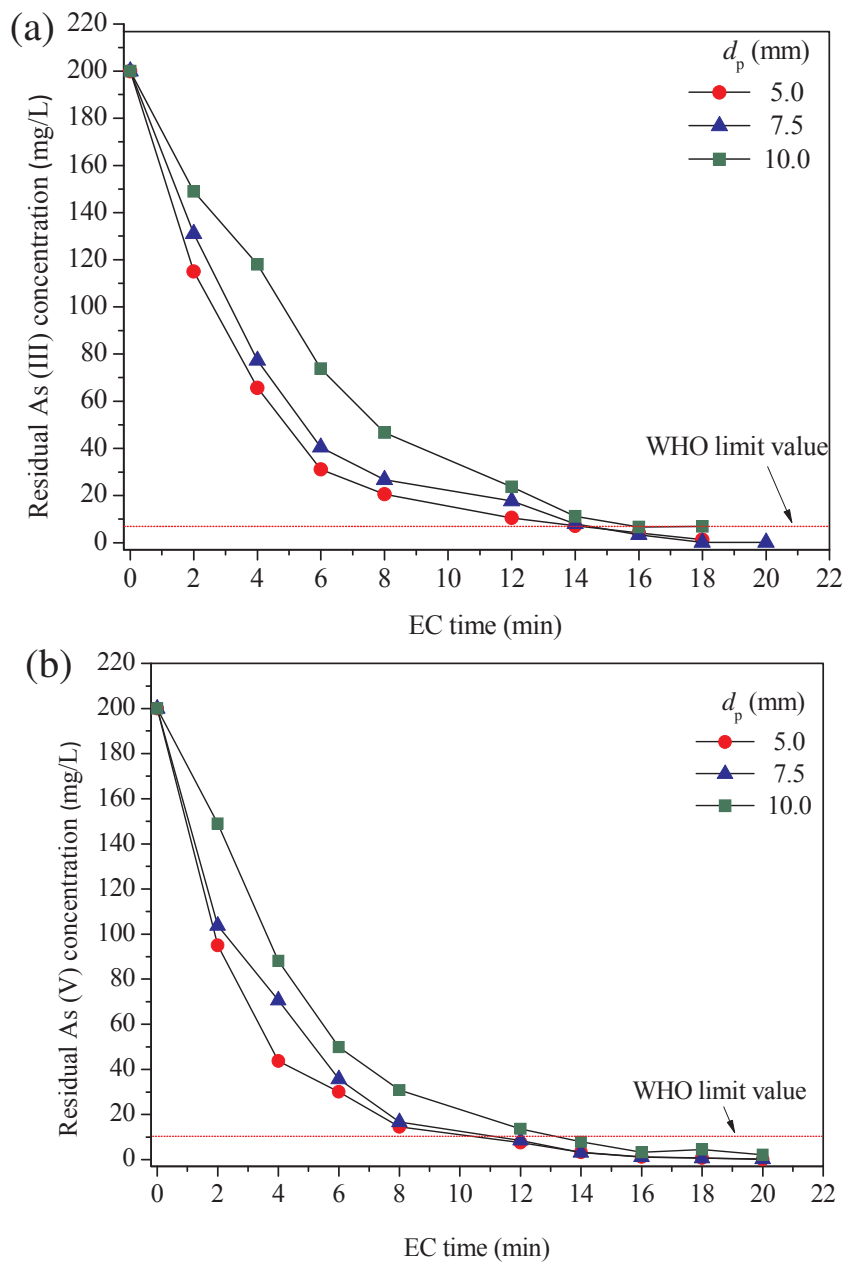

Fig. 7. Effect of diameter of Fe ball anode on (a) $\mathrm{As}(\mathrm{III})$ and (b) $\mathrm{As}(\mathrm{V})$ removal efficiencies (Operating conditions: $C_{\mathrm{o}}=200 \mu \mathrm{g} / \mathrm{L}, \mathrm{pH}_{\mathrm{i}}=7.5, i=0.30 \mathrm{~A}, h=5 \mathrm{~mm}, Q_{\text {air }}=6 \mathrm{~L}$ / $\min )$.

$0.13188 \mathrm{~m}^{2}\left(2.28 \mathrm{~A} / \mathrm{m}^{2}\right)$ for $5.0 \mathrm{~mm}, 0.07592 \mathrm{~m}^{2}\left(3.95 \mathrm{~A} / \mathrm{m}^{2}\right)$ for $7.50 \mathrm{~mm}$, and $0.03454 \mathrm{~m}^{2}\left(8.69 \mathrm{~A} / \mathrm{m}^{2}\right)$ for $10 \mathrm{~mm}$. From these results, increased $d_{\mathrm{p}}$ at constant $\mathrm{Fe}$ anode height in the EC reactor increased current density because of decreased total $\mathrm{Fe}$ anode surface area. Fe electrode consumptions and removed As per mg Fe of generated electrochemically at 5.0, 7.5 and $10 \mathrm{~mm}$ of Fe ball anodes were calculated as $75.12 \mathrm{mg}$ and $2.57 \mu \mathrm{g} / \mathrm{mg}$ ( $C E$ of $103 \%, C_{\text {theo }}$ of $72.93 \mathrm{mg}$ ), $75.19 \mathrm{mg}$ and $2.55 \mu \mathrm{g} / \mathrm{mg}$ ( $C E$ of $103.1 \%, C_{\text {theo }}$ of $72.93 \mathrm{mg}$ ) and $84.19 \mathrm{mg}$ and $2.30 \mu \mathrm{g} / \mathrm{mg}$ (CE of $101 \%, C_{\text {theo }}$ of $83.35 \mathrm{mg}$ ) for As(III) removal, and $66.27 \mathrm{mg}$ and $2.91 \mu \mathrm{g} / \mathrm{mg}$ (CE of $105.8 \%, C_{\text {theo }}$ of $62.51 \mathrm{mg}$ ), $62.76 \mathrm{mg}$ and $3.05 \mu \mathrm{g} / \mathrm{mg}$ ( $C E$ of $100.4 \%, C_{\text {theo }}$ of $62.51 \mathrm{mg}$ ), and $76.20 \mathrm{mg}$ and $2.52 \mu \mathrm{g} / \mathrm{mg}$ ( $C E$ of $104.5 \%, C_{\text {theo }}$ of $72.93 \mathrm{mg}$ ) for As(V) removal, respectively. Amounts of sludge at 5.0, 7.5 and $10 \mathrm{~mm}$ were determined as $0.148,0.139$ and $0.143 \mathrm{~kg} / \mathrm{m}^{3}$ for As(III) removal and $0.135,0.144$ and $0.138 \mathrm{~kg} / \mathrm{m}^{3}$ for As(V) removal, respectively. Average voltages between anode and cathode electrodes in the EC reactor at 5.0, 7.5 and $10 \mathrm{~mm}$ were measured as 19.3, 20.6 and $22.4 \mathrm{~V}$ for As(III) removal and 19.8, 23.1 and $22.9 \mathrm{~V}$ for $\mathrm{As}(\mathrm{V})$ removal.

\subsection{Effect of Fe ball anode height}

Another important parameter with regard to electrode life time and arsenic removal efficiency is Fe ball anode height in the EC reactor. The effect of the ball height was studied with the experimental conditions at $6 \mathrm{~L} / \mathrm{min}, 7.5 \mathrm{~cm}, 0.30 \mathrm{~A}$, a $\mathrm{pH}_{\mathrm{i}}$ of 7.5 for the groundwater sample containing $200 \mu \mathrm{g} / \mathrm{L}$ of arsenic. The results are shown in Fig. 8. When value of $h$ in the EC reactor increased, the arsenic removal efficiency
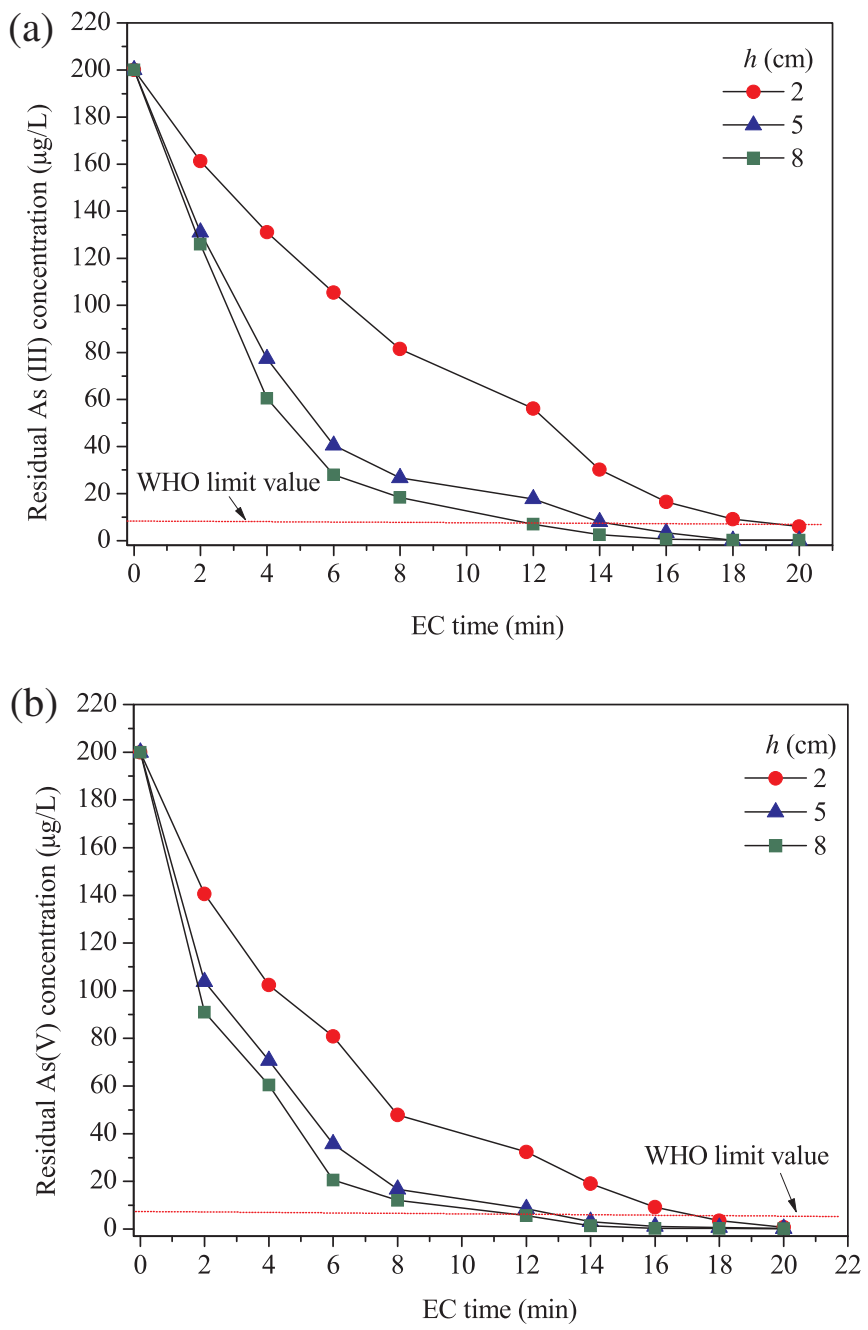

Fig. 8. Effect of anode height in the EC reactor on (a) As(III) and (b) $\mathrm{As}(\mathrm{V})$ removal efficiencies.

increased because of increase in amount of iron ball anodes or total iron anode surface area. Total anode surface area for anode heights of 2, 5 and $8 \mathrm{~cm}$ in the EC reactor were calculated as $0.03179 \mathrm{~m}^{2}, 0.07595 \mathrm{~m}^{2}$, and $0.11657 \mathrm{~m}^{2}$, respectively. According to the Faraday law, increasing $h$ value meant increasing both surface area of anode and dissolved amount of metal ions. Consequently, there was an increase for both As (III) and As(V) removal efficiencies related to $h$ value. Minimum EC times and effluent arsenic concentrations for electrode heights of 2, 5, and $8 \mathrm{~cm}$ in the EC reactor were $18 \mathrm{~min}$ and $9.12 \mu \mathrm{g} / \mathrm{L}, 14 \mathrm{~min}$ and $8.01 \mu \mathrm{g} / \mathrm{L}, 12 \mathrm{~min}$ and $6.99 \mu \mathrm{g} / \mathrm{L}$ for As(III) removal and $16 \mathrm{~min}$ and $9.10 \mu \mathrm{g} / \mathrm{L}, 12 \mathrm{~min}$ and $8.50 \mu \mathrm{g} / \mathrm{L}, 12 \mathrm{~min}$ and $5.71 \mu \mathrm{g} / \mathrm{L}$ for $\mathrm{As}(\mathrm{V})$ removal.

On the other hand, the minimum charge loadings required for the arsenic removal efficiency above $95 \%$ (or $C_{\mathrm{f}}<10 \mu \mathrm{g} / \mathrm{L}$ ) at anode height of 2,5 , and $8 \mathrm{~cm}$ in the EC reactor were calculated as 324,252 , and 216C for As(III) removal and 288, 216, and 216C for As(V), respectively. According to the above results, the charge loading decreased with an increase of anode height. In this case, amounts of electrochemically generated iron and current efficiency at minimum EC times (or coagulant dosage) were found to be $95.928 \mathrm{mg}$ Fe and $102.3 \%$ for $h$ of $2 \mathrm{~cm}, 75.194 \mathrm{mg} \mathrm{Fe}$ and $103.1 \%$ for $h$ of $5 \mathrm{~cm}$, and $65.265 \mathrm{mg} \mathrm{Fe}$ and $104.4 \%$ for $h$ of $8 \mathrm{~cm}$ for As(III) removal and $86.103 \mathrm{mg} \mathrm{Fe}$ and $103.3 \%$ for $h$ of $2 \mathrm{~cm}, 62.764 \mathrm{mg} F$ and $100.4 \%$ for $h$ of $5 \mathrm{~cm}$, and $66.453 \mathrm{mg}$ Fe and $106.3 \%$ for $h$ of $8 \mathrm{~cm}$ for As(V) removal, respectively. Amount of removed arsenic per $\mathrm{mg} F$ for anode height of 2,5 and $8 \mathrm{~cm}$ in EC reactor at minimum EC times were calculated as $1.99 \mu \mathrm{g} / \mathrm{mg}, 2.55 \mu \mathrm{g}$ / 
$\mathrm{mg}$, and $2.96 \mu \mathrm{g} / \mathrm{mg}$ for As(III) removal, and $2.22 \mu \mathrm{g} / \mathrm{mg}, 3.05 \mu \mathrm{g} / \mathrm{mg}$, and $2.92 \mu \mathrm{g} / \mathrm{mg}$ for $\mathrm{As}(\mathrm{V})$ removal, respectively. Amounts of sludge at the optimum EC times for $h$ of 2, 5 and $8 \mathrm{~cm}$ were calculated as 0.183 , 0.139 and $0.118 \mathrm{~kg} / \mathrm{m}^{3}$ for As(III) removal and $0.176,0.144$ and $0.121 \mathrm{~kg} / \mathrm{m}^{3}$ for As $(\mathrm{V})$ removal, respectively. Average voltages between anode and cathode electrodes in the EC reactor at h of 2, 5 and $8 \mathrm{~cm}$ were measured as 20.4, 20.6 and $20.3 \mathrm{~V}$ for As(III) removal and 23.8, 23.1 and 23.4 $\mathrm{V}$ for $\mathrm{As}(\mathrm{V})$ removal. As height of Fe ball anodes (amount of iron ball anodes) in the EC reactor for both arsenic species was increased, the required operating time decreased to obtain the recommended effluent arsenic concentration. This was important for changing of electrodes and maintenance of the process. Therefore, it would be an advantage to run the EC process at low cost.

\section{Conclusions}

In the present study, electrocoagulation was evaluated as a treatment technology for removals of As(III) and As(V) from the groundwater. The results indicated that the arsenic removal efficiency increased with increase in current, air flow rate, anode height in the reactor and operating time, but it decreased with the increase in both initial concentration and diameter of iron ball anode. Effect of $\mathrm{pH}$ on arsenic removal was not significant in the $\mathrm{pH}$ range of 6.5-8.5. The highest effects on the removal of efficiencies of As(III) and As(V) from the groundwater were observed with column height in the reactor and current. The maximum removal efficiency and minimum operating cost at a $\mathrm{pH}_{i}$ of 7.5, $0.3 \mathrm{~A}, 200 \mu \mathrm{g} / \mathrm{L}$, ball diameter of $7.5 \mathrm{~mm}, h$ of $5 \mathrm{~cm}$ and $Q_{\text {air }}$ of $6 \mathrm{~L} / \mathrm{min}$ were $96.0 \%$ and $0.612 \$ / \mathrm{m}^{3}$ at $14 \mathrm{~min}$ for As(III), and $95.8 \%$ and $0.546 \$ / \mathrm{m}^{3}$ at $12 \mathrm{~min}$ for $\mathrm{As}(\mathrm{V})$, respectively. It can be concluded from this study that the electrocoagulation with iron ball anodes is a promising technique for the removal of arsenic.

\section{Acknowledgement}

The authors would like to express their appreciation for the financial support of TUBITAK (The Scientific and Technical Research Council of Turkey, Project Number $=111$ Y103).

\section{References}

[1] P. Ravenscroft, H. Brammer, K. Richards, Arsenic Pollution: A Global Synthesis RGS IBG Book Series, A John Wiley \& Sons Publication Ltd., London, 2009.

[2] A. Mukherjee, M.K. Sengupta, M.A. Hossain, S. Ahamed, B. Das, B. Nayak, D. Lodh, M.M. Rahman, D. Chakraborti, Arsenic contamination in groundwater: a global perspective with emphasis on the Asian scenario, J. Health Popul. Nutr. 24 (2006) 142-163.

[3] P.L. Smedley, D.G. Kinniburgh, A review of the source, behaviour and distribution of arsenic in natural waters, Appl. Geochem. 17 (2002) 517-568.

[4] V.K. Sharma, M. Sohn, Aquatic arsenic: toxicity, speciation, transformations, and remediation, Environ. Int. 35 (2009) 743-759.

[5] T.S.Y. Choong, T.G. Chuah, Y. Robiah, F.L.G. Koay, I. Azni, Arsenic toxicity, health hazards and removal techniques from water: an overview, Desalination 217 (2007) 139-166.

[6] WHO (World Health Organisation), Arsenic in Drinking-water, World Health Organization, Switzerland-Geneva, 2001 (Fact Sheet No. 210).

[7] USEPA (United States Environmental Protection Agency), Implementation Guidance for the Arsenic Rule, Environmental Protection Agency, Government Printing Office, Washington, D.C, 2002, pp. 6976-7066 (EPA-816-K-02-018).

[8] J.L. Barringer, Z. Szabo, T.P. Wilson, J.L. Bonin, T. Kratzer, K. Cenno, T. Romagna, M. Alebus, B. Hirst, Distribution and seasonal dynamics of arsenic in a shallow lake in north western New Jersey, USA, Environ. Geochem. Health 33 (2011) 1-22.

[9] M. Dogan, A.U. Dogan, Arsenic mineralization, source, distribution, and abundance in the Kutahya region of the western Anatolia, Turkey, Environ. Geochem. Health 29 (2007) 119-129.

[10] M. Colak, U. Gemici, G. Tarcan, The effects of colemanite deposits on the arsenic concentrations of soil and groundwater in Igdeköy-Emet, Kutahya, Turkey, Water Air Soil Pollut. 149 (2003) 127-143.

[11] C. Ozkul, E. Ciftci, N. Koprubasi, S. Tokel, M. Savas, Geogenic arsenic anomalies in soils and stream waters of Neogene Emet basin (Kütahya-Western Turkey), Environ. Earth Sci. 73 (2015) 6117-6130.

[12] M. Col, C. Col, Arsenic concentrations in the surface, well, and drinking waters of the Hisarcik, Turkey, Hum. Ecol. Risk Assess.: Int. J. 10 (2004) 461-465.

[13] U. Gemici, G. Tarcan, C. Helvaci, A.M. Somay, High arsenic and boron concentrations in groundwaters related to mining activity in the Bigadic borate deposits (Western Turkey), Appl. Geochem. 23 (2008) 2462-2476.

[14] O. Gunduz, C. Simsek, A. Hasozbek, Arsenic pollution in the groundwater of Simav Plain, Turkey: its impact on water quality and human health, Water Air Soil Pollut. 205 (2010) 43-62.

[15] N. Aksoy, C. Simsek, O. Gunduz, Groundwater contamination mechanism in a geothermal field: a case study of Balcova, Turkey, J. Contam. Hydrol. 103 (2009) $13-28$.

[16] G. Yuce, D.U. Yasin, Assessment of an increase in boron and arsenic concentrations at the discharge area of Na-borate mine (Kirka-Eskisehir, Turkey), Terr. Atmos. Oceanic Sci. J. 23 (2012) 703-723.

[17] A. Cicek, R. Balkis, A. Ugurluoglu, E. Kose, C. Tokatli, The effects of large borate deposits on groundwater quality, Pol. J. Environ. Stud. 22 (2013) 1031-1037.

[18] W. Driehaus, M. Jekel, U. Hildebrandt, Granular ferric hydroxide-a new adsorbent for the removal of arsenic from natural water, J. Water Supply: Res. Technol. AQUA 47 (1998) 30-35.

[19] T. Viraraghavan, K. Subramanian, J. Aruldoss, Arsenic in drinking water-problems and solutions, Water Sci. Technol. 40 (1999) 69-76.

[20] J.R. Parga, D.L. Cocke, J.L. Valenzuela, J.A. Gomes, M. Kesmez, G. Irwin, H. Moreno, M. Weir, Arsenic removal via electrocoagulation from heavy metal contaminated groundwater in La Comarca Lagunera Mexico, J. Hazard. Mater. 124 (2005) 247-254.

[21] M. Kobya, F. Ozyonar, E. Demirbas, E. Sik, M.S. Oncel, Arsenic removal from groundwater of Sivas-Şarkişla Plain, Turkey by electrocoagulation process: comparing with iron plate and ball electrodes, J. Environ. Chem. Eng. 3 (2015) 1096-1106.

[22] P. Song, Z. Yang, G. Zeng, X. Yang, H. Xu, L. Wang, R. Xu, W. Xiong, K. Ahmad, Electrocoagulation treatment of arsenic in wastewaters: a comprehensive review, Chem. Eng. J. 317 (2017) 707-725.

[23] P.V. Nidheesh, T.S.A. Singh, Arsenic removal by electrocoagulation process: recent trends and removal mechanism, Chemosphere 181 (2017) 418-432.

[24] S. Amrose, S.R.S. Bandaru, C. Delaire, C.M. van Genuchten, A. Dutta, A. DebSarkar, C. Orr, J. Roy, A. Das, A.J. Gadgil, Electro-chemical arsenic remediation: field trials in west bengal, Sci. Total Environ. 488-489 (2014) 539-546.

[25] M. Kobya, F. Ulu, U. Gebologlu, E. Demirbas, M.S. Oncel, Treatment of potable water containing low concentration of arsenic with electrocoagulation: different connection modes and Fe-Al electrodes, Sep. Purif. Technol. 77 (2011) 283-293.

[26] E. Sik, M. Kobya, E. Demirbas, M.S. Oncel, A.Y. Goren, Removal of As(V) from groundwater by a new electrocoagulation reactor using Fe ball anodes: optimization of operating parameters, Desalin. Water Treat. 56 (2015) 1177-1190.

[27] Standard Methods for the Examination of Water and Wastewater, 21st edition, APHA (American Public Health Association), Washington, D.C, 2016, p. 2005.

[28] T. Banerji, S. Chaudhari, Arsenic removal from drinking water by electrocoagulation using iron electrodes- an understanding of the process parameters, J. Environ. Chem. Eng. 4 (2016) 3990-4000.

[29] G. Ona-Nguema, G. Morin, F. Juillot, G. Calas, G.E. Brown, EXAFS analysis of arsenite adsorption onto two-line ferrihydrite, hematite, goethite, and lepidocrocite, Environ. Sci. Technol. 39 (2005) 9147-9155.

[30] J. Gimenez, M. Martinez, J.D. Pablo, M. Rovira, L. Duro, Arsenic sorption onto natural hematite, magnetite, and goethite, J. Hazard. Mater. 141 (2007) 575-580.

[31] S. Dixit, J.G. Hering, Comparison of arsenic(V) and arsenic(III) sorption onto iron oxide minerals: implications for arsenic mobility, Environ. Sci. Technol. 37 (2003) 4182-4189.

[32] P.R. Kumar, S. Chaudhari, K.C. Khilar, S.P. Mahajan, Removal of arsenic from water by electrocoagulation, Chemosphere 55 (2004) 1245-1252.

[33] X. Chen, G. Chen, P.L. Yue, Separation of pollutants from restaurant wastewater by electrocoagulation, Sep. Purif. Technol. 19 (2000) 65-76.

[34] H.K. Hansen, P. Nunez, D. Raboy, I. Schippacasse, R. Grandon, Electrocoagulation in wastewater containing arsenic: comparing different process designs, Electrochim. Acta 52 (2007) 3464-3470.

[35] L.S. Thakur, M. Prasenjit, Simultaneous arsenic and fluoride removal from synthetic and real groundwater by electrocoagulation process: parametric and cost evaluation, J. Environ. Manage. 190 (2017) 102-112.

[36] K.S. Hashim, A. Shaw, R.Al. Khaddar, M.O. Pedrola, Iron removal, energy consumption and operating cost of electrocoagulation of drinking water using a new flow column reactor, J. Environ. Manage. 189 (2017) 98-108.

[37] K.S. Hashim, A. Shaw, R.Al. Khaddar, M.O. Pedrola, D. Phipps, Defluoridation of drinking water using a new flow column-electrocoagulation reactor (FCER) - experimental, statistical, and economic approach, J. Environ. Manage. 197 (2017) $80-88$.

[38] K.S. Hashim, A. Shaw, R.Al. Khaddar, M.O. Pedrola, Controlling water temperature during the electrocoagulation process using an innovative flow column-electrocoagulation reactor, Int. J. Environ. Chem. Ecol. Geol. Geophys. Eng. 9 (2015) 964-967.

[39] V. Kuokkanen, T. Kuokkanen, J. Ramo, U. Lassi, Recent applications of electrocoagulation in treatment of water and wastewater-A review, Green Sustain. Chem. 3 (2013) 89-121.

[40] E. Lacasa, P. Canizares, M.A. Rodrigo, F.J. Fernandez, Electro-oxidation of As(III) with dimensionally-stable and conductive-diamond anodes, J. Hazard. Mater. 203-204 (2012) 22-28. 